\title{
The Brazilian stock market of the new millennium: an efficiency test
}

\author{
Luiz Eduardo Gaio ${ }^{\dagger}$ \\ University of São Paulo \\ Karina Lumena de Freitas Alves ${ }^{\Omega}$ \\ University of São Paulo \\ Tabajara Pimenta Júnior ${ }^{\Psi}$ \\ University of São Paulo
}

\begin{abstract}
According to the Hypothesis of Efficient Market - HME, proposed by Fama (1970), in its weak form, an investor doesn't get to predict the stock returns based on historical returns and thus doesn't get abnormal returns in a consistent way. This paper is concerned verifying HME, in the weak form, in the Brazilian stock market by the analysis of fifty more negotiated stocks in BOVESPA since 2000 until 2007. The methodology was used based in the ARIMA models of time series and serial correlation tests of returns to prove or not the random behavior of the stock returns. The results had shown that Brazilian capital market did not evidence characteristics of an efficient market, in the weak form, in the considered period.
\end{abstract}

Key-words: Market efficiency; capital markets; random walk; abnormal returns.

Received in 30/06/2008; revised in 10/12/2008; accept in 18/03/2009.

\footnotetext{
Corresponding authors:

${ }^{\dagger}$ University of São Paulo

Address: Rua Aldo Focosi, 205,

Campus USP, Ribeirão Preto - SP -

Brazil - CEP: 14091310

Telefhone.: (16) 8807-1886

e-mail:lugaio@yahoo.com.br
}

${ }^{\Omega}$ University of São Paulo - Escola de Engenharia de São Carlos Address: Viriato Fernandes Nunes, 30, Santa Paula, São Carlos - SP Brazil - CEP: 13564070

Telephone.: (16) 3413-3949

e-mail: karinalumena@yahoo.com
${ }^{\Psi}$ University of São Paulo Address: Av. Bandeirantes, 3900, Monte Alegre - Ribeirão Preto- SP Brazil - CEP: 14040-900 Telephone.: (16)3602-4820 e-mail:taba.jr@terra.com.br

Editor's note: This paper was accepted by Antonio Lopo Martinez. 


\section{INTRODUÇÃO}

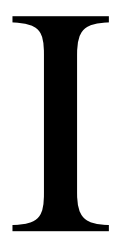

$\mathrm{n}$ the 50s, fundamental changes started to occur in the field of knowledge of corporate and market finance (JENSEN; SMITH, 1984). The complexity of the structures of the organizations and changes in the financial market brought to an end the use of quantitative methods for decision-making. According to Bodie, Kane and Marcus (2000), one for the first financial investments occurred with time series, and a strong candidate was the behavior in time of share prices.

In the mid 50s there was evidence that the behavior of share prices approximated the so-called random path (FAMA, 1970). The signs that these prices behaved randomly brought concerns to investors at a time when this hypotheses seemed to insinuate irrationality in the market. However, as cited by Bodie, Kane and Marcus (2000), this randomness indicated an efficient market, all the information on a certain company is incorporated into the price of its asset quickly and correctly by investors.

The assumption of randomness in the behavior of shares can be found when there is not a systematic relationship between current and past returns. Thus, there would be no way for an investor to obtain extraordinary gains based on an analysis of past prices, to the extent that all the past information would already be incorporated into the current price.

When this assumption is confirmed, the market is classified as efficient in weak form. According to Fama (1970) in weak form tests the information of interest is only that of past prices and randomness is confirmed when the serial correlation is zero. Fama and French (1988) added that if this correlation approximates zero, studies consider it economically insignificant and randomness is confirmed.

Testing efficiency in capital markets presupposes to assess if the returns follow a balanced behavior, without large gains or losses by investors. The rejection of the efficiency assumption generates two interpretations: the first is that the capitals market is not efficient, and its prices do not follow equilibrium, and the second is that the market is efficient, but its prices do not follow equilibrium, i.e., they are poorly specified. In light of these interpretations, knowledge of the predictability of returns is quite relevant for the development of the academic investigation.

The proposal of this work consists in answering the following question: Can the Brazilian shares market be considered efficient in weak form?

The Hypothesis of Efficient Market (HME) can be analyzed from three aspect in connection with their qualification, the market being characterized as efficient in weak form, semi-strong and strong (FAMA, 1970). However, the study was based only on analyzing the Weak Efficiency Hypothesis in the Brazilian shares market.

To the HME in weak form, in this study, the serial correlation between current and past returns on shares traded at BOVESPA (São Paulo Stock Exchange) was analyzed.

\section{BIBLIOGRAPHICAL REVIEW}

The first studies performed to test the market efficiency hypothesis in the US market obtained results, which supported this hypothesis (MINARDI, 2001). From then on, a vast series of works was published on the theme. According to Jensen and Smith (1985) the Hypothesis of Efficient Market is perhaps the most tested hypothesis in all social science.

The need to test the Hypothesis of Efficient Market can be observed due to the importance of using quantitative methods to help in investment decisions in a shares market subject to constant variations. 
Statisticians such as Working (1934), Kendall (1953) and Osborne (1959, 1962) showed the share prices behave randomly. This hypothesis called random walk has been tested in the years to evidence the efficiency of a given market.

To say that, in an efficient market model, the current price of an asset reflects in full all the available information is the same as to say that successive prices are independent (FAMA, 1970). In other words, there is no predictability of future prices by means of an analysis of past prices because the behavior of these prices is random.

However, there is evidence that is contrary to random walk in the analysis of the behavior of shares. In the last decades, studies emerged with financial asset prices showing adverse results to those found by the creators of the Hypothesis of Efficient Market.

Santos, Costa Jr. and Silveira (2003) showed that the behavior of the prices of the future contracts analyzed approximated more the random walk model than the behavior of share prices, for which, one cannot confirm randomness. Other studies, such as those of Fama and French (1988), Lo and Mackinley (1988), French and Roll (1986) and Jegadeesh (1990), pointed to the existence of a correlation between returns of historic series of share prices, positively or negatively.

However, Minardi (2001) added that although the existence of serial correlations of past returns confirms the possibility of prediction of share returns, it is not clear that analyses produce significant economic results, capable of invalidating the random walk model for the behavior of share prices. Thus, according to the author, the validity of the randomness hypothesis is confirmed not only with the occurrence of correlations among returns, but instead when the use of this information does not bring significant gains to the investor.

It is noted, however, according to Minardi (2001), the need to assess the significance of the results achieved, i.e., to test if the returns achieved with the analysis of past prices are significant and if, thus, it is possible that investors have extraordinary gains by strategic means based on the result of the analysis of past prices.

In this work, Minardi (2001), tested the Hypothesis of Efficient Market in Brazil with data from 649 shares quoted between 1994 and 2000. The author divided her work into three stages, analyzing first the existence of correlation between individual shares returns. Second, through the prediction of share returns, she analyzed the existence of economic gains and finally constructed portfolios with winning and losing shares to analyze two investment strategies.

In her work, Minardi (2001) concluded that in addition to a certain degree of predictability existing while analyzing past returns of individual shares, economic gains are significant, going against the randomness hypothesis and consequently the Hypothesis of Efficient Market. However, the author pointed out that by managing shares portfolios, there were no significant gains in using the moment strategy and the adverse strategy, which goes against previous results as those pointed out by Jegadeesh and Titmam (1993 e 1999) and De Bondt and Thaler (1985).

While Jegadeesh and Titmam (1993 and 1999) concluded that the Moment Strategy brought significant gains to investors in a short-term horizon, De Bondt and Thaler (1985) pointed out the Adverse strategy brought returns to short-term investors, i.e., investors who make significant gains by buying shares or portfolios that had a lower performance in previous times and sell those that had superior performance in the past.

In her studies, Dall Agnoll (2001) showed, similar to De Bondt and Thaler (1985), the Adverse Strategy brings extraordinary returns to investors. However, according to the author, the strategy of buying losing portfolios and selling winning portfolios brought abnormal 
returns to investors both in the short and long term, and not only as attested by De Bondt and Thaler (1985). The author reached this result after analyzing a corresponding sample to the series of monthly returns of shares traded in Bovespa and in Soma during the period January 1986 and July 2000.

On the other hand, works such as Saffi (2003) and Neto and Carmona (2005) presented evidence of efficiency in the Brazilian capitals market. Based on the results he obtained, Saffi (2003) concluded that the strategy based on past data was the fruit of change, which corroborated the market efficiency hypothesis in weak form for the Brazilian market. The author achieved this result by analyzing, through the use of the technical analysis strategies, a series of daily prices of futures contracts with the Bovespa index (Ibovespa) traded between June 1992 and January 2002.

The strategies based on Technical Analysis, also referred to as Graphist Analysis, take into consideration past prices to predict future prices. The confirmation of extraordinary gains by investors using graphist analysis would imply the rejection of efficiency in weak form. However, as mentioned by Saffi (2003), the conclusion of works using Technical Analysis to validate the prediction of this strategy is based only on the observation of a price series. The author added that it may be probable that, among thousands of different strategies based on Technical Analysis, some present superior performance and this could only be the fruit of chance. When this hypothesis is taken into consideration, one says that the results took into account data-snooping effects.

The results of Saffi (2003) indicated that one of the 14,630 technical analysis strategies was capable of generating statistically significant results to investors taking into account the data-snooping effects, which confirms the Hypothesis of Efficient Market in weak form. It should be stressed that the author achieved this result by analyzing the prices of contracts in futures markets, and was not geared to the shares market with other studies reported herein.

Like Saffi (2003), Santos, Costa Jr. and Silveira (2003) find weak market evidence when analyzing the prices of futures contracts in Brazil. The authors investigated the occurrence of gains in the Brazilian market from 1996 to 1999 for the futures market and from 1990 and 2000 for the stock market and, using self-correlation tests, they found that the behavior of the futures contracts prices was closed to the random walk mode that that of stocks.

Neto and Carmona (2005) find evidence of efficiency, in weak form, in the Brazilian stock market. The authors justified their differences by arguing that previous studies conducted in Brazil, whose results evidence significant gains for investors, are in periods of consideration inflation, which may lead to the problem of bias in the sample data.

To investigate the evidence of abnormal returns to investors, or also the so-called phenomenon of overreaction, known as the exaggerated behavior of investors in relation to what would be the appropriate price of assets, Neto and Carmona tested the Hypothesis of Efficient Market in Brazil in the period 1994-2004, post Real Plan.

Using a sample of 98 shares traded in Bovespa, the authors created winning and losing portfolios for each interval, 6 months, 12 months, 18 months and 24 months. The authors compared the respective behaviors and did not find evidence of abnormal returns in the Brazilian stock market, which corroborates the randomness hypothesis.

However, in a similar period, from 2001 to 2005, the studies of Barbosa and Medeiros (2007) pointed out evidence of overreaction. However differently from Neto and Carmona (2005), Barbosa and Medeiros (2007) analyzed the behavior of share prices in the Brazilian market to find the existence of efficiency after favorable or unfavorable events (or shocks), 
understood as events which bring impacts to the economy or financial markets of a country. While one analyzed the efficiency of the semi-strong market and the other analyzed the efficiency of the market in weak form, which could explain the difference.

Given the differences pointed out in connection with market efficiency in the Brazilian stock market, as well as results in connection with the strategy that lead to significant gains to the investor, one notes the importance of such studies. However, it should be emphasized that the research cited was conducted in different times and markets, which could justify such difference. Hence, the importance and need to updates in the literature, made by new works related to market efficiency.

\section{METHODOLOGY}

\subsection{Type of research}

This research can also be classified as descriptive and quantitative. Descriptive due to its objective, to give a description or make an analysis of data for a sample of return on same shares traded in BOVESPA (MARTINS and THEÓPHILO, 2007). Quantitative, due to the approach to the problem, as the resources used to analyze the data consist of statistical methods. (MARTINS and THEÓPHILO, 2007).

The study is of a bibliographical nature, as it makes a review of the literature in connection with research and studies in the formation of a construction. In the view of Santos and Parra Filho (1998), bibliographical research is necessary to know previously the state in which the matter to be researched found itself in, regardless of to which field of knowledge it belongs.

According to Fachin (2003, p. 102), bibliographical research consists of a "set of knowledge gathers in works which are fundamentally based in leading the reader to a certain subject, production, [...] and use". Therefore, the collection in the bibliography together with the qualitative comparisons, adds value to the existing discussion.

\subsection{Research data}

The daily closing prices of the 50 most liquid shares traded in BOVESPA in the period from January 1, 2000 to September 11, de 2007 on the database ECONOMÁTICA® were collected.

The data were treated by the program Excel excluding Saturdays, Sundays, holidays and days when there was no trading, and the program Eviews 5 was used for statistical methods.

\subsection{Analysis of the data}

To analyze the historic series of the daily returns of the 5 most liquid shares traded in BOVESPA, stationarity and normality, self-correlation check, random walk check and evidence of return to average tests were conducted. Another investigation made concerning obtaining abnormal returns based on the strategies described in the previous item was made.

To test normality, the Jarque-Bera test was applied, accompanied by its p-value, i.e., the probability of not rejecting the null hypothesis that the series follows a normal standard. The trust level defined was $95 \%$. The stationarity test was conducted through the increased 
Dickey-Fuller test, also accompanied by its p-value, i.e., the probability of a series presenting a unit root. The trust gap adopted will be, as well as in the normality test, $95 \%$.

The serial correlation analysis was made from coefficients of the self-correlation function (FAC), accompanied by the Ljung-Box test. Self-correlation is found when at least one of the two self-correlation coefficients is different from zero and when the p-value of the statistics Q of Ljung-Box is small enough to reject the null hypothesis, of series not presenting self-correlation. An interval of 95\% trust was considered both for the selfcorrelation coefficients different from zero and for the Ljung-Box test.

Another analysis also found refers to the possibility of past returns being capable of predicting future returns, i.e., if there is the possibility of construction of prediction models for stock returns. For this, the methodology of temporal series was used, through the prediction models Self-regressive (AR(1)), model of Mobile Averages (MA(1)) and Self-regressive and Mobile Averages models (ARMA(1,1)), as described by Morettin and Toloi(2004).

The verification of the random path occurred based on the results of the analyses described above.

The analysis of the verification of the return to average also depends on the previous results in connection with stationarity, but added to another analysis made from the observation of the self-correlation coefficients observed in the self-correlation function.

The investigation conducted for verification of abnormal returns through the use of strategies was based on the methodology adopted by Jegadeesh and Titman (1993).

\subsection{Normality Test (Jarque-Bera)}

The objective of the normality test, proposed by Bera \& Jarque (1981), is to test if a certain series follows a normal distribution behavior. According to Morettim and Toloi (2004), if a series is considered normal (Gaussian), its behavior may be described by a linear model, of the ARMA type.

Basically, the test statistics measures the difference of asymmetry and kurtosis of a certain series with those of a normal distribution.

Thus, given the asymmetry and kurtosis coefficient expressed by:

$$
\begin{aligned}
& S=\frac{1}{N} \sum_{i=1}^{N}\left(\frac{Y_{i}-Y}{\sigma}\right)^{3} \\
& K=\frac{1}{N} \sum_{i=1}^{N}\left(\frac{Y_{i}-Y}{\sigma}\right)^{4}
\end{aligned}
$$

In which $\mathrm{S}$ corresponds to the asymmetry coefficient, $\mathrm{K}$ of kurtosis, represents the series in instant $\mathrm{t}$, its respective standard deviation value and $\mathrm{N}$ the number of observations. Jarque-Bera's statistics can be, then, estimated according to the expression:

$$
\text { Jarque }- \text { Bera }=\frac{N-k}{6} \mid\left(\begin{array}{c}
S^{2}+\frac{(K-3)}{2} \mid \\
4
\end{array}\right)
$$

In which $\mathrm{k}$ represents the number of coefficients estimated used to generate the series. 
Based on Jarque-Bera's statistics, normality is tests from comparison of its values with those obtained on a distribution table $t$ with 2 degrees of liberty, the null hypothesis is that in which the series follows normal distribution. The test can also be, calculating the p-value of the test, given the value obtained from the statistics.

\subsection{Unit Root Test (Dickey-Fuller)}

The main purpose of the unit root test is to determine if a temporal series is stationary in level or if it becomes stationary in the differences. From the different types of tests found in the literature, one choose to use the Dickey \& Fuller (DF) and Dickey \& Fuller Increased (ADF) tests.

The Dickey \& Fuller (DF) test involved prediction of the equation (4) by the method of Minimum Ordinary Squares (MQO), and subsequently it tests the hypothesis (5) of presence of unit root. It is interesting to stress that the use of the DF test will be valid when the series generated by a self-regressive are in the order of one and their random terms follow a white noise. Therefore, if the process generating a temporal series is a self-regressive one of order superior to one $[\mathrm{AR}(\mathrm{p})$, where $(\mathrm{p}>1)]$, the test to be used corresponds to the Dickey \& Fuller Increased (ADF), which consists in estimating the equation (6) by the MQO and test the hypothesis (7):

Dickey \& Fuller (DF) Test

$$
\Delta Y_{t}=\alpha+(\theta-1) Y_{t-1}+\gamma T+u_{t}
$$

where, e are coefficients to be predicted by the MQO regression corresponds to series in the first difference of instant $t$, the white noise and $\mathrm{T}$ represents the determinist trend.

Hypothesis test:

$$
\begin{gathered}
H_{0}: \theta-1=0 \\
H_{a}: \theta-1<0
\end{gathered}
$$

Dickey \& Fuller Increased (ADF) Test

$$
\Delta Y_{t}=\alpha+\beta Y_{t-1}+\sum_{i=1}^{p-1} \omega_{t} \Delta Y_{t-1}+\gamma T+u_{t}
$$

Where $\beta=\sum_{i=1}^{p} \theta_{i}-1$ e $\omega=-\sum_{j=i+1}^{p} \theta_{j}$

Hypothesis test:

$$
\begin{gathered}
H_{0}: \beta=0 \\
H_{a}: \beta<0
\end{gathered}
$$




\subsection{Stationarity Test (Ljung-Box statistics)}

Another statistic also used to test stationarity is statistic Q, developed by Box and Pierce and subsequently reviewed by Ljung and Box.

According to Gujarati (2000), to test the joint hypothesis that all the self-correlation coefficients are simultaneously equal to zero, one can use statistic Q of Box and Pierce, defined as:

$$
Q=n \sum_{k=1}^{m}{\hat{\rho_{k}}}^{2}
$$

Where $\mathrm{n}$ is the size of the sample and $\mathrm{m}$ the gap duration.

Statistic $\mathrm{Q}$ is distributed approximately as the chi-square distribution with $\mathrm{m}$ degrees of liberty. In an application, if the Q calculated exceeds the critical value of Q of the chi-square table by the chosen level of significance, we can reject the null hypothesis that all are equal to zero, at least some of them must be different from zero.

A variant of Box-Pierce's Q statistic is the statistic of Ljung-Box (LB), defined as:

$$
L B=n(n+2) \sum_{k=1}^{m}\left(\frac{\hat{\rho}_{k}^{2}}{n-k}\right) \sim \chi_{m}^{2}
$$

Even though, in large sample, both statistic Q and LB follow the chi-square distribution with degrees of liberty, the LB statistic has been proving to have greater properties in small samples that statistic Q.

\subsection{Temporal Series Models}

The self-regressive models (AR) were introduced by Yule in 1926, while the mobile average (MA) models appeared around 1937. According to Morettin and Toloi (2004), any discreet stationary model can be represented by self-regressive and mobile average models (ARMA).

In 1970, Box and Jenkins developed a good technique for prediction and control models in temporal series. The technique, based on probabilistic and prediction error minimization analysis generates iteratively predicted model. Like every mode, it presents some limitations of application, such as the observations in the same which must be greater than 50 occurrences.

Based then on the Box \& Jenkins methodology, the self-regressive model of order $p$, $\mathrm{AR}(\mathrm{p})$, can be represented by:

$$
Y_{t}=\phi_{1} Y_{t-1}+\phi_{2} Y_{t-2}+\ldots+\phi_{p} Y_{t-p}+\varepsilon_{t}
$$

And the Mobile Average Model or order q, MA(q), is represented as:

$$
Y_{t}=\theta_{1} \varepsilon_{t-1}-\theta_{2} \varepsilon_{t-2}-\ldots-\theta_{q} \varepsilon_{t-q}+e_{t}
$$


Therefore, according to the generalization of Box \& Jenkins, from a differentiated temporal series of order (I) one has model ARMA(p,q) given by:

$$
Y_{t}=\phi_{1} Y_{t-1}+\ldots+\phi_{p} Y_{t-p}+\varepsilon_{t}-\theta_{1} \varepsilon_{t-1}-\ldots-\theta_{q} \varepsilon_{t-q}+e_{t}
$$

where represents the series in time $t$, is a random error i.i.d (independent and identically distributed), with .

\section{RESULTS AND DISCUSSION}

As the result of the market efficiency analysis of the Brazilian capitals market , through statistical tests, one obtained Table 1, which contains the result of the three tests, as well as their characteristics and p-value of interpretation.

As presented in item 3.2, the companies listed in Table 1 correspond to the organizations which have greatest liquidity indices with their capital in the São Paulo Stock Exchange.

In other words, these are the most traded firms in Bovespa. It should be stressed that in certain cases, one has the values related to common and preferred shares analyzed independently.

To determine if the behavior of the shares follow a normal distribution, as inferred from item 3.3, through the Normality Test of Jarque Bera (Table 1), one observes that in almost all cases, the returns follow a behavior according to the densities of Gaussian probability (normal distribution), as their p-values of direct interpretation all signified $1 \%$ and for some of them only to $5 \%$.

However, the returns of the company Eletropaulo did not show a behavior in accordance with Gaussian density.

This can be explained by the low number of observations, given that, for this case, only 252 data were held. In other words, a relatively small number, in order to build an efficiency test statistic and a distribution, and preventing, therefore, devising possible inferences for the whole.

Generally speaking, one can then affirm that there is strong indication of weak efficiency in the Brazilian capitals market, as the majority of companies have a normal distribution behavior for the returns on their assets.

Regarding the Unit Root Test, proposed by Dickey-Fuller (Table 1), one observes that the returns of all the companies analyzed do not have a unit root, which leads us to conclude that they are stationary, given that their p-values significant of $1 \%$ for all cases. 
Table 1: Statistical tests to measure market efficiency

\begin{tabular}{|c|c|c|c|c|c|c|c|c|}
\hline \multirow[t]{2}{*}{ Code } & \multirow[t]{2}{*}{ Company } & \multicolumn{2}{|c|}{ Normality Test } & \multicolumn{2}{|c|}{ Stationarity Test } & \multicolumn{3}{|c|}{ Ljung-Box Test } \\
\hline & & Statistic & p-value & Statistic & $p$-value & 1 & 10 & 20 \\
\hline PETR4 & PETROBRAS & 177.29 & 0.00 & -31.34 & 0.00 & 0.00 & 0.00 & 0.0 \\
\hline VALE5 & VALE R DOCE & 117.74 & 0.00 & -32.11 & 0.00 & 0.02 & 0.00 & 0.0 \\
\hline BBDC4 & BRADESCO & 154.19 & 0.00 & -31.12 & 0.00 & 0.00 & 0.00 & 0.0 \\
\hline USIM5 & USIMINAS & 48.81 & 0.00 & -30.24 & 0.00 & 0.00 & 0.00 & 0.0 \\
\hline VALE3 & VALE R DOCE & 163.96 & 0.00 & -32.16 & 0.00 & 0.08 & 0.01 & 0.0 \\
\hline ITAU4 & ITAUBANCO & 52.94 & 0.00 & -32.19 & 0.00 & 0.00 & 0.00 & 0.0 \\
\hline GGBR4 & GERDAU & 142.70 & 0.00 & -29.61 & 0.00 & 0.00 & 0.04 & 0.1 \\
\hline UBBR11 & UNIBANCO & 440.67 & 0.00 & -31.02 & 0.00 & 0.05 & 0.03 & 0.0 \\
\hline CSNA3 & SID NACIONAL & 73.60 & 0.00 & -29.59 & 0.00 & 0.00 & 0.00 & 0.0 \\
\hline PETR3 & PETROBRAS & 353.98 & 0.00 & -32.34 & 0.00 & 0.00 & 0.00 & 0.0 \\
\hline ITSA4 & ITAUSA & 22.64 & 0.00 & -32.34 & 0.00 & 0.61 & 0.03 & 0.0 \\
\hline ALLL11 & ALL AMER LAT & 13.69 & 0.00 & -17.26 & 0.00 & 0.10 & 0.01 & 0.0 \\
\hline BBAS3 & BRASIL & 144.11 & 0.00 & -33.16 & 0.00 & 0.53 & 0.26 & 0.2 \\
\hline TNLP4 & TELEMAR & 184.04 & 0.00 & -31.50 & 0.00 & 0.04 & 0.18 & 0.0 \\
\hline NETC4 & NET & 1395.48 & 0.00 & -29.02 & 0.00 & 0.55 & 0.00 & 0.0 \\
\hline CMIG4 & CEMIG & 27.13 & 0.00 & -32.51 & 0.00 & 0.20 & 0.00 & 0.0 \\
\hline GOLL4 & GOL & 107.89 & 0.00 & -19.41 & 0.00 & 0.61 & 0.96 & 0.5 \\
\hline CSAN3 & COSAN & 8.62 & 0.01 & -14.41 & 0.00 & 0.01 & 0.05 & 0.1 \\
\hline BRAP4 & BRADESPAR & 444.74 & 0.00 & -31.42 & 0.00 & 0.01 & 0.08 & 0.2 \\
\hline TAMM4 & TAM S/A & 32.03 & 0.00 & -14.83 & 0.00 & 0.00 & 0.02 & 0.0 \\
\hline CYRE3 & CYRELA REALT & 8.34 & 0.01 & -15.19 & 0.00 & 0.41 & 0.44 & 0.7 \\
\hline AMBV4 & AMBEV & 1687.11 & 0.00 & -32.14 & 0.00 & 0.30 & 0.00 & 0.0 \\
\hline CESP6 & CESP & 546.81 & 0.00 & -13.78 & 0.00 & 0.18 & 0.19 & 0.4 \\
\hline NATU3 & NATURA & 528.80 & 0.00 & -20.20 & 0.00 & 0.13 & 0.05 & 0.1 \\
\hline ELET6 & ELETROBRAS & 117.43 & 0.00 & -30.48 & 0.00 & 0.28 & 0.10 & 0.0 \\
\hline TCSL4 & TIM PART S/A & 132.33 & 0.00 & -30.18 & 0.00 & 0.95 & 0.52 & 0.0 \\
\hline BRKM5 & BRASKEM & 230.38 & 0.00 & -29.13 & 0.00 & 0.00 & 0.00 & 0.0 \\
\hline PRGA3 & PERDIGAO S/A & 48.44 & 0.00 & -12.82 & 0.00 & 0.96 & 0.40 & 0.6 \\
\hline LREN3 & LOJAS RENNER & 35.10 & 0.00 & -16.38 & 0.00 & 0.12 & 0.07 & 0.0 \\
\hline ELET3 & ELETROBRAS & 49.43 & 0.00 & -29.78 & 0.00 & 0.00 & 0.00 & 0.0 \\
\hline CCRO3 & CCR RODOVIAS & 2866.90 & 0.00 & -26.50 & 0.00 & 0.07 & 0.00 & 0.0 \\
\hline VIVO4 & VIVO & 2320.18 & 0.00 & -29.62 & 0.00 & 0.00 & 0.14 & 0.1 \\
\hline SDIA4 & SADIA S/A & 135.17 & 0.00 & -32.88 & 0.00 & 0.52 & 0.09 & 0.1 \\
\hline ARCZ6 & ARACRUZ & 186.82 & 0.00 & -31.80 & 0.00 & 0.04 & 0.00 & 0.0 \\
\hline CPLE6 & COPEL & 46.12 & 0.00 & -32.01 & 0.00 & 0.14 & 0.04 & 0.1 \\
\hline EMBR3 & EMBRAER & 1212.78 & 0.00 & -31.58 & 0.00 & 0.87 & 0.71 & 0.5 \\
\hline GFSA3 & GAFISA & 2133.88 & 0.00 & -12.09 & 0.00 & 0.26 & 0.02 & 0.0 \\
\hline LAME4 & LOJAS AMERIC & 833.06 & 0.00 & -30.95 & 0.00 & 0.01 & 0.00 & 0.0 \\
\hline GOAU4 & GERDAU MET & 62.85 & 0.00 & -29.23 & 0.00 & 0.00 & 0.00 & 0.0 \\
\hline ELPL6 & ELETROPAULO & 1.04 & 0.59 & -11.59 & 0.00 & 0.23 & 0.09 & 0.1 \\
\hline BRTO4 & BRASIL TELEC & 383.30 & 0.00 & -31.50 & 0.00 & 0.02 & 0.03 & 0.0 \\
\hline CPFE3 & CPFL ENERGIA & 29.61 & 0.00 & -18.68 & 0.00 & 0.07 & 0.12 & 0.0 \\
\hline TNLP3 & TELEMAR & 2732.61 & 0.00 & -30.88 & 0.00 & 0.79 & 0.89 & 0.8 \\
\hline DURA4 & DURATEX & 144.59 & 0.00 & -30.95 & 0.00 & 0.38 & 0.63 & 0.3 \\
\hline
\end{tabular}




$\begin{array}{ccccccccc}\text { PCAR4 } & \text { P.ACUCAR-CBD } & 188.54 & 0.00 & -30.14 & 0.00 & 0.00 & 0.09 & 0.6 \\ \text { VCPA4 } & \text { V C P } & 144.47 & 0.00 & -30.64 & 0.00 & 0.76 & 0.30 & 0.0 \\ \text { BRTP4 } & \text { BRASIL T PAR } & 146.40 & 0.00 & -31.45 & 0.00 & 0.07 & 0.02 & 0.0 \\ \text { SBSP3 } & \text { SABESP } & 150.47 & 0.00 & -32.07 & 0.00 & 0.24 & 0.31 & 0.1 \\ \text { KLBN4 } & \text { KLABIN S/A } & 175.98 & 0.00 & -33.93 & 0.00 & 0.00 & 0.00 & 0.0\end{array}$

Note: the Normality Test adopted is the Jarque-Bera test. The Unit Root Test is the Dickey-Fuller test with its statistic F. The stationarity test corresponds to the Ljung-Box test for the 3 gap levels, in lags 1, 10, and 20, and their presented values correspond to the p-value of the chi-square statistic.

In other words, the data of Table 1 evidence that the returns of the stocks of Brazilian companies follow a normal distribution, in their majority, and do not have any type of trend, if behaving within an average of 0 and standard deviation, which reinforces the indication that the Brazilian market is efficient.

Analyzing the result of the Ljung-Box Stationarity Test for share returns, at the levels of 1,10 and 20 gaps, it is found that only 22 types of stocks, from the 50 analyzed, i.e., $44 \%$ of them, appeared not significant to $10 \%$ for the first lag, 15 (30\%) for lag 10 and 18 (36\%) for lag 20 , this means that only the returns of these stock are stationary and do not present self-correlation among the lags, according to the teststatistics.

From these results, one can notice that not all the markets have a certain stationarity and serial correlation among their returns, which evidences that circa $64 \%$ of the Brazilian market, taking into consideration the statistics to lag 20, cannot be considered efficient.

To determine the presence of serial correlation and predictive capacity of the returns of Brazilian stocks, according to item 3.2, the next stage deal with the prediction of temporal serial models and test to determine if such models can be considered as a proxy of prediction of returns. It should be recalled that a market can only be considered efficient when its returns follow the Random Walk behavior, or, in other words, past values cannot influence future values, preventing their prediction through lagged returns.

Table 2 contains the statistical result of the F Test for models $\operatorname{AR}(1), \operatorname{MA}(1)$ and $\operatorname{ARMA}(1,1)$ adjusted to the returns of the 50 most liquid shares in the Brazilian capitals market.

Analyzing model AR(1) (Table 2), one notices only 46\% of the shares analyzed do not present self-correlations in their returns, as the self-regressive models were not significant when adjusted to the series. This indicates that, for these shares, the values of past returns cannot be used for future gains or losses to be estimated, and that the market follows a random walk, which reinforces the idea of weakefficiency.

Regarding model MA(1), the reality is even smaller, as only $42 \%$, at a level of $10 \%$ were not significant. This demonstrates that, in a majority of $58 \%$ of papers analyzed, models can be used to measure future returns.

For model ARMA(1,1), one has a percentage of $36 \%$ of stocks for which one does not succeed in building a temporal series prediction model $\operatorname{ARMA}(1,1)$, as there were no significant results at the level of $10 \%$, for test F. 
Table 2: Result of the temporal series models

\begin{tabular}{|c|c|c|c|c|c|c|c|}
\hline \multirow[t]{2}{*}{ Code } & \multirow[t]{2}{*}{ Company } & \multicolumn{2}{|c|}{$\mathbf{A R}(\mathbf{1})$} & \multicolumn{2}{|c|}{ MA(1) } & \multicolumn{2}{|c|}{$\operatorname{ARMA}(\mathbf{1}, \mathbf{1})$} \\
\hline & & Statistics & $p$-value & Statistics & $p$-value & Statistics & $\begin{array}{c}p- \\
\text { value }\end{array}$ \\
\hline PETR4 & PETROBRAS & 19,70 & 0,00 & 22,40 & 0,00 & 12,06 & 0,00 \\
\hline VALE5 & VALE R DOCE & 5,35 & 0,02 & 6,11 & 0,01 & 7,59 & 0,00 \\
\hline BBDC4 & BRADESCO & 11,71 & 0,00 & 12,92 & 0,00 & 9,24 & 0,00 \\
\hline USIM5 & USIMINAS & 17,86 & 0,00 & 18,61 & 0,00 & 9,63 & 0,00 \\
\hline VALE3 & VALE R DOCE & 3,03 & 0,08 & 3,45 & 0,06 & 5,26 & 0,00 \\
\hline ITAU4 & ITAUBANCO & 7,74 & 0,00 & 9,02 & 0,00 & 6,53 & 0,00 \\
\hline GGBR4 & GERDAU & 11,08 & 0,00 & 10,99 & 0,00 & 5,55 & 0,00 \\
\hline UBBR11 & UNIBANCO & 3,83 & 0,05 & 4,06 & 0,04 & 4,66 & 0,00 \\
\hline CSNA3 & SID NACIONAL & 17,13 & 0,00 & 17,07 & 0,00 & 8,56 & 0,00 \\
\hline PETR3 & PETROBRAS & 16,28 & 0,00 & 19,84 & 0,00 & 14,74 & 0,00 \\
\hline ITSA4 & ITAUSA & 0,26 & 0,61 & 0,29 & 0,59 & 3,72 & 0,02 \\
\hline ALLL11 & ALL AMER LAT & 2,69 & 0,11 & 2,83 & 0,09 & 1,49 & 0,23 \\
\hline BBAS3 & BRASIL & 0,39 & 0,53 & 0,45 & 0,50 & 1,68 & 0,19 \\
\hline TNLP4 & TELEMAR & 4,43 & 0,03 & 4,89 & 0,03 & 4,31 & 0,01 \\
\hline NETC4 & NET & 0,36 & 0,55 & 0,32 & 0,56 & 1,65 & 0,19 \\
\hline CMIG4 & CEMIG & 1,61 & 0,20 & 1,86 & 0,17 & 1,36 & 0,25 \\
\hline GOLL4 & GOL & 0,27 & 0,60 & 0,26 & 0,61 & 0,13 & 0,97 \\
\hline CSAN3 & COSAN & 7,91 & 0,00 & 8,52 & 0,00 & 4,15 & 0,02 \\
\hline BRAP4 & BRADESPAR & 7,52 & 0,00 & 7,96 & 0,00 & 6,84 & 0,00 \\
\hline TAMM4 & TAM S/A & 18,87 & 0,00 & 17,66 & 0,00 & 9,47 & 0,00 \\
\hline CYRE3 & CYRELA REAL & 0,67 & 0,41 & 0,65 & 0,42 & 5,85 & 0,00 \\
\hline AMBV4 & AMBEV & 1,05 & 0,31 & 1,16 & 0,28 & 9,14 & 0,00 \\
\hline CESP6 & CESP & 2,13 & 0,15 & 4,22 & 0,04 & 1,19 & 0,31 \\
\hline NATU3 & NATURA & 2,42 & 0,12 & 2,61 & 0,11 & 1,21 & 0,30 \\
\hline ELET6 & ELETROBRAS & 1,17 & 0,28 & 1,17 & 0,28 & 1,34 & 0,26 \\
\hline TCSL4 & TIM PART S/A & 0,00 & 0,94 & 0,00 & 0,95 & 1,37 & 0,25 \\
\hline BRKM5 & BRASKEM & 17,85 & 0,00 & 17,58 & 0,00 & 9,90 & 0,00 \\
\hline PRGA3 & PERDIGAO S/A & 0,00 & 0,96 & 0,00 & 0,96 & 0,00 & 0,99 \\
\hline LREN3 & LOJ. RENNER & 2,47 & 0,11 & 2,58 & 0,11 & 1,23 & 0,29 \\
\hline ELET3 & ELETROBRAS & 8,83 & 0,00 & 8,78 & 0,00 & 4,60 & 0,01 \\
\hline CCRO3 & CCR RODOV. & 3,25 & 0,00 & 3,45 & 0,06 & 2,63 & 0,07 \\
\hline VIVO4 & VIVO & 8,44 & 0,00 & 8,31 & 0,00 & 4,24 & 0,01 \\
\hline SDIA4 & SADIA S/A & 0,43 & 0,51 & 0,48 & 0,49 & 3,41 & 0,03 \\
\hline ARCZ6 & ARACRUZ & 4,15 & 0,04 & 4,23 & 0,04 & 4,17 & 0,01 \\
\hline CPLE6 & COPEL & 2,21 & 0,13 & 2,31 & 0,13 & 6,88 & 0,00 \\
\hline EMBR3 & EMBRAER & 0,03 & 0,87 & 0,03 & 0,87 & 0,47 & 0,62 \\
\hline GFSA3 & GAFISA & 1,52 & 0,22 & 1,47 & 0,22 & 2,97 & 0,05 \\
\hline LAME4 & LOJAS AMERIC & 5,93 & 0,01 & 6,36 & 0,01 & 3,82 & 0,02 \\
\hline GOAU4 & GERDAU MET & 15,93 & 0,00 & 15,62 & 0,00 & 8,06 & 0,00 \\
\hline ELPL6 & ELETROPAULO & 1,45 & 0,23 & 1,48 & 0,22 & 1,66 & 0,19 \\
\hline BRTO4 & BRASIL TELEC & 5,25 & 0,02 & 5,77 & 0,02 & 3,60 & 0,03 \\
\hline CPFE3 & CPFL ENERGIA & 3,29 & 0,07 & 3,35 & 0,07 & 1,70 & 0,18 \\
\hline TNLP3 & TELEMAR & 0,07 & 0,79 & 0,07 & 0,78 & 0,60 & 0,55 \\
\hline
\end{tabular}




\begin{tabular}{lccccccc} 
DURA4 & DURATEX & 0,76 & 0,38 & 0,78 & 0,38 & 0,57 & 0,57 \\
PCAR4 & P.ACUCAR & 8,38 & 0,00 & 8,55 & 0,00 & 4,69 & 0,01 \\
VCPA4 & V C P & 0,09 & 0,76 & 0,09 & 0,76 & 0,05 & 0,95 \\
BRTP4 & BRASIL T PAR & 3,22 & 0,07 & 3,49 & 0,06 & 2,43 & 0,09 \\
SBSP3 & SABESP & 1,38 & 0,24 & 1,54 & 0,21 & 0,69 & 0,50 \\
KLBN4 & KLABIN S/A & 21,65 & 0,00 & 23,93 & 0,00 & 16,79 & 0,00 \\
\hline
\end{tabular}

Note: The test statistic used refers to Statistic F

Generally speaking, the data of Table 2 demonstrated, through estimation of models $\operatorname{AR}(1), \operatorname{MA}(1)$ and $\operatorname{ARMA}(1,1)$, that, for the majority of stocks analyzed, their past returns serve as proxy for measuring future gains and losses (more than $50 \%$ of cases). This result reinforces the hypothesis that the Brazilian stock market evidences characteristics of an efficient market in weak form.

\section{CONCLUSION}

The objective of this study was to test if the Brazilian stock market can be considered efficient in its weak form. Using a sample made up of the 50 most traded companies in the São Paulo Stock Exchange (Bovespa), in the period from January 1 to September 11, 2007, one could test the Hypothesis of Efficient Market.

To analyze the HME in the historic series of daily returns of the 50 most liquid companies traded in BOVESPA, stationary and normality tests were conducted, as well as determination of self-correlation, random walk and evidence of return to average. Another investigation was conducted regarding obtaining abnormal returns.

The results achieved in the normality, stationarity and self-correlation tests of residues indicated that not all the market papers have a certain stationary and serial correlation in their returns. A total of $64 \%$ of the papers showed a behavior not compatible with that of an efficient market, taking into account Ljung-Box statistic to lag 20.

The results presented by the prediction of models AR(1), MA(1) and ARMA(1,1) to the returns of stocks demonstrated that, for the majority of stocks analyzed, their past returns serve as proxy to measure future gains and losses (more than $50 \%$ of the cases). This result reinforces the idea that the Brazilian stock market does not evidence characteristics of an efficient market in weak form.

The conclusion that the Brazilian stock market, represented here by the 50 most traded liquid shares of Bovespa is not efficient in weak form, as established by the HME proposed by Fama (1970), and in light of the tests conducted herein, matches other studies already conducted, as was the case of the studies of Santos, Costa Jr. and Silveira (2003), Fama and French (1988), Lo and Mackinley (1988), French and Roll (1986) and Jegadeesh (1990) and Saffi (2003), who also evidenced that the market is not efficient.

The characteristics of the Brazilian stock market in a new phase of development in the beginning of this new millennium, and the good phase through which it passed in the last seven years (growth, enhancement and appreciation), did not affect the condition of inefficient market detected in other studies performed in previous periods.

This result can serve as a reference to possible investors, demonstrating that the behavior of stock prices does not reflect all the information available to the public, in other 
words, it confirms the assumption that there are small groups of investors who have privileged information to act in the market, generating abnormal gains.

To finalize, the limitations of this work, such as the restricted number of companies analyzed, must be highlighted, corresponding to approximately $15 \%$ of the total publicly held companies in Brazil, but which correspond to more than $80 \%$ of the trading volume of the Stock Exchange, the use of a specific period for analysis and the probabilistic nature of results. Thus, the results presented herein do not intend to provide a complete analysis of efficiency in the Brazilian capitals market, but instead to put back into discussion a crucially important theme for fund managers, portfolio administrators and other participants of this market.

For future works, one suggests to conduct an enhancement of this study with the application of different econometric and statistic techniques to test the presence of random walk and possible predictive capacities in the Brazilian stock market. One also suggest a wider study, incorporating not only analysis of informational efficiency in weak form, but also, in its strong and semi-strong forms.

\section{REFERENCES}

BARBOSA, G.C.; MEDEIROS, O. R. Teste empírico da eficiência do mercado brasileiro na ocorrência de eventos favoráveis e desfavoráveis. Revista de Negócios, v. 12, n. 4, p.44-54, out/dez 2007.

BERA, A.K.; JARQUE, C.M. An efficient large sample test for normality of observations and regression residuals. Working paper in Econometrics, n. 49,1981

BODIE, Z.; KANE, A.; MARCUS, A.J. Fundamentos de investimentos. Tradução: Robert Brian Taylor. $3^{\mathrm{a}}$ ed. Porto Alegre: Bookman, 2000. 632 p.

DALL`AGNOL, IVANA. Retornos anormais e estratégias reversas. 2001.73 f. Dissertação (Mestrado em Economia ) - Escola de Pós-Graduação em Economia, Fundação Getúlio Vargas, Rio de Janeiro, 2001.

DE BONDT, W.F.M.; THALER, R. Does the stock market overreact? Journal of Finance, v. 40, n. 3, p. 793-805, jul. 1985.

FACHIN, O. Fundamentos de metodologia. 4. ed. São Paulo: Saraiva, 2003.

FAMA, E.F. Efficient capital market: a review of theory and empirical work. Journal of Finance, v. 25, n. 2, p. 383-417, mai. 1970.

FAMA, E.F.; FRENCH, K.R. Permanent and temporary components of stock prices. Journal of Political Economy, v. 96, n. 2, p. 246-273, abr. 1988.

FRENCH, K.R.; ROLL, R. Stock return variances: the arrival of information and the reaction of traders. Journal of Financial Economics, v. 17, n. 1, p. 5-26, set. 1986.

GUJARATI, D. N. Econometria Básica. 3 ed. São Paulo: Pearson, 2000, 846 p.

JEGADEESH, N. Evidence of predictable behavior of security returns. Journal of Finance, v. 45, n. 3, p. 881-898, jul. 1990.

JEGADEESH, N.; TITMAN, S. Returns to buying winners and selling losers: implications for stock market efficiency. Journal of Finance, v. 48, n. 1., p. 65-91, mar. 1993. 
JENSEN, M.C.; SMITH JR., C.W. The theory of corporate finance: a historical overview. The Modern Theory of Corporate Finance, p. 2-20, 1984.

KENDALL, M. The analysis of economics time series: part 1: prices. Journal of the Royal Statistical Society, v. 96, p. 11-25, 1953.

LAKATOS, E.M.; MARCONI, M.A. Metodologia científica. 4ª ed. São Paulo: Atlas, 2004. $312 \mathrm{p}$.

LO, A.W.; MACKINLAY, A.C. Stock market prices do not follow random walks: evidence from a simple specification test. Review of Financial Studies, v. 1, n. 1, p. 41-66, 1988.

MARTINS, G. A. ; THEÓPHILO, C. R. Metodologia da Investigação Científica para Ciências Sociais Aplicadas. São Paulo: Atlas, 2007.

MINARDI, A.M.A.F. Preços passados prevendo desempenho de ações brasileiras.

Financelab Working Paper, set.-2001.

MORETTIN, P.A.; TOLOI, C. M. C. Análise de Séries Temporais. São Paulo: Edgard Blücher, 2004.

NETO, J.W.F.; CARMONA, C.U.M. Eficiência do mercado acionário brasileiro pós-Plano Real: Há evidências de overreaction ?. XXV Encontro Nacional de Engenharia de Produção, ABEPRO, p.2266 - 2273, 2005.

OSBORNE, M.F.M. Brownian motion in the stock market. Operations Research, v. 7, n. 2 , p 145-173, mar. 1959.

OSBORNE, M.F.M. Periodic structure in the brownian motion of stock prices. Operations Research, v. 10, n. 3, p 345-379, mai. 1962.

SAFFI, P. A. C. Análise Técnica: Sorte ou realidade? Revista Brasileira de Economia, v. 57, n.4, p. 953-974. 2003

SANTOS, J. A, PARRA FILHO, D. Metodologia Científica. SP: Futura, 1998.

SANTOS, A.A.P.; COSTA JR., N.C.A.; SILVEIRA, J.S.T. Efficiency gains and the random walk hypothesis in the Brazilian future and stock markets during the 90's. Revista Alcance, n. 2, 2003.

WORKING, H. A random-difference series for use in the analysis of time series. Journal of the American Statistical Association, v. 29, n. 185, p 11-24. 1934. 